\title{
Historical Representation as Resurrection: Al-Udfuwī and the Imitation of Allāh
}

\author{
Evan Metzger
}

1 The Significance of Al-Udfuwì’s al-Ṭāli al-Sa'ìd

In commencing his exceptional study of Qūṣ, the important medieval regional center that produced so many 'ulam $\bar{a}$ ' in the $13^{\text {th }}$ and $14^{\text {th }}$ centuries, JeanClaude Garcin noted that “notre étude n' aurait guère eu de sens, si nous n' avions disposé du dictionnaire biographique des notabilités du haut Sa’id composé à l'époque mammelouke."1 The biographical dictionary to which he was referring, so essential to his study and, indeed, to any study of Upper Egypt

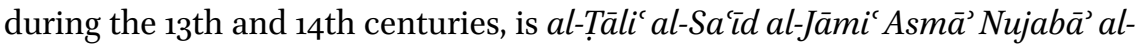
Șaìd by Kamāl al-Dīn Ja'far b. Tha'lab al-Udfuwī (d. 748/1347). ${ }^{2}$

This biographical history is a unique source for Mamluk history. Its extraordinary nature and value are due to not only its inclusion of 594 biographies, including four women who were either born or spent a considerable amount of time in Upper Egypt, but also the detailed geographical description of Upper Egypt that al-Udfuwi included at the beginning of the text. It should be noted for the sake of accuracy that al-Udfuwi's Upper Egypt begins around Ikhmìm and ends by Aswan at the border of Nuba - the area known as al-Ṣa $\bar{\imath} d$ al-A $A^{\imath} \bar{a}-$ and not everything south of the Giza up to Aswan. Beyond this introductory geographical description, the bulk of the text is dedicated to biographies of various individuals who were either born in Upper Egypt or lived there for a large part of their lives. The vast majority of these individuals died in either the $7^{\text {th }} / 13^{\text {th }}$ or 8 th/14th century and are mostly scholars or poets.

Because al-Udfuwi's text is the only biographical dictionary dedicated solely to Upper Egypt written during this period to have been preserved (and likely the only one written during the premodern period at all), it has long been mined as a source of information about the condition and people of the region. This is a centuries-old tradition. One of the earliest Westerners to have done this

1 Garcin, Centre, introduction xi.

2 Al-Isnawī, Ṭabaqāt i, 86; al-Maqrīzī, Muqaffā iii, 23; Sulūk iv, 94; al-Ṣafadī, Wāfı̀ xi, 77-8; Ibn Hajar, Durar i, 535-7; Ibn Qādī Shuhba, Tabaqāt iii, 22-5; Ibn al-Imād, Shadharāt viii, 263-4. 
was the 17th-century German theologian Johann Vansleb, who briefly refers to the text in his account of his travels to Egypt as an authority on the time it takes to traverse Upper Egypt. ${ }^{3}$ Later historians also recognized the value of alUdfuwi's text. His biographies were recycled, often in truncated form, in the historical works of major Mamluk-era historians like al-Subkī (d. 771/1370), alȘafadī (d. 764/1363), and al-Maqrīzì (d. 845/1442). ${ }^{4}$

So, when Garcin wrote his history of Qūs, he was following the deep tracks of a tradition of relying on this same text for knowledge about the Șaìd. Garcin was not uncritical of his interaction with the text. He acknowledged that a biographical dictionary was a constructed text that only provided a glimpse of the affairs of the people of Qūs.. ${ }^{5}$ Nevertheless, his study's main engagement was not with the way in which history was constructed within the text. The same can be said for other contemporary authors who have turned to al-Udfuwi's work as an "archive" of Upper Egyptian medieval Muslim history. ${ }^{6}$ Al-Udfuwì's work has achieved a high level of objectivity within the scholarship on the period, and its entries are often treated as having the accuracy of "reports," but the grounds for this positivity has never been questioned.

Hence, despite centuries of scholarly tradition, al-Udfuwìs history has yet to receive any scrutiny as a text, although al-Taa $l i^{\text {c }}$ displays many of the features of the new literary-historical style characteristic of the "Literarisierung" of Mamluk-era historiographical texts to which Ulrich Haarmann first drew our attention: the frequent inclusion of anecdotes and mirabilia, the use of poetry and $s^{\prime} j^{c}$ to adorn the historical narrative, and the attempt to equalize histori-

3 Wansleben, Present 13, where he writes, "Giafer ibn Daleb, an Arabian Historian, saith that it is twelve days journey long, as they march with Camels in Egypt, but it is not above four Hours travelling from side to side in the Country that is inhabited: for if we should comprehend in the breadth the Mountains of Sand on the East and West, it is a great deal broader than we have said."

4 Al-Ṣafadī states about al-Udfuwī, "He composed al-Tālic al-Sa ìd fí Tarīkh al-Ṣa ìd, and he wrote it with skill (wa-jawwadahu). I have copied several biographies from that history," in Wãfi xi, 78. Similarly, al-Maqrīzī noted in his biography of al-Udfuwī in al-Muqaffā that "I have copied a lot from it (al-Tālic al-Sa'id) in this book, and it is a precious book (kitäb nafis) that contains useful stories and biographies not found elsewhere," al-Muqaffä iii, 23. Al-Subkī does not cite al-Udfuwī, but it is clear that he relied on al-Udfuwī's biographies due to the word-for-word similarity of some of the entries, such as in the biography of Taqī al-Dīn b. Daqīq al-'̄̃d in al-Subkī, Tabaqāt, 207-49.

5 Garcin, Centre, introduction xi-xii.

6 The term "archive" as applied to biographical dictionaries is from Cooperson, Classical, preface xi, where he notes that "biography is the archive of the Muslims." For studies besides Garcin's that rely on al-Udfuwī as a main source, see Hofer, Popularisation; Gril, al-Uqșurī; al-Qinā̄ìi; and, to some extent, el-Leithy, Sufis. 
ographical units regardless of the significance of the content. ${ }^{7}$ By including the latter feature - the equalizing of historiographical units-Haarmann was referring to the tendency of Mamluk authors of chronicles to standardize the length of entries of each year in order to approach an "aesthetic reminiscent of adab." 8 While his study of "Literarisierung" emphasized chronicles and mostly excluded biographical works, al-Udfuwīs biographical dictionary does manifest a similar tendency to produce balanced entries. Arranged alphabetically by name, the text includes an entry for every single letter, a feat which pushed al-Udfuwi to search for individuals he otherwise would not have included were it not for the letter commencing their first name. In al-Udfuwi's words, "I do not mention living individuals but rarely, and always for a reason: either due to a dearth of names for one letter, due to the individual's having virtues or extraordinary charm, or due to the individual's having bestowed upon me some kindness or good deed."9 Like Ibn Khallikān, al-Udfuwī's biographical dictionary was only supposed to include entries of dead people, but the desire to create an aesthetically complete history that also performed the sociological function of paying back one's social debts led him to break his own principle of inclusion.

Thus, al-Udfuwìs text, bristling with anecdotes, poetry, and aestheticized language, is ripe for a literary analysis. While one could document all of these different literary features indicative of the "Literarisierung der inneren Form," this is not the approach I will take. ${ }^{10}$ Rather, it is suggested here that historiographical form and content cannot be analytically separated in their entirety. Using an integrated approach to form and content, I show how one of the most boilerplate, apparently formal components of the text-the tahmìd - is itself a signifier with meaningful content independent, at times, of the apparent referent of its language. By understanding the literary standards of the tahmid, one can perceive an intended meaning that transcends the purely aesthetic by artfully employing the literary standards of the age. In the case of al-Taa $l i$, as I argue below, the meaning signified by the form is that the biographies, in all their diversity, are true representations of past lives which, whatever heterodoxy they display, are worthy of remembrance.

At the same time, and due to this very heterodoxy, the text is not univocal. The Tă $l^{i}$, for a number of different reasons specific to al-Udfuwì's historical situation as a liminal individual in both scholarly and religious affiliation and

\footnotetext{
Haarmann, Auflösung 55-6.

Ibid. 56 .

Al-Udfuwī, al-Ṭălic 6.

Haarmann, Auflösung 49 .
} 
his provincial origins, exhibits Bakhtinian heteroglossia, a concept defined below. Al-Udfuwi's particular use of the khutba is one legitimizing form for this heteroglossia. Another is the need to represent different madhhabs or genres. Moreover, the authority of the Upper Egyptian shuyūkh, even the most pious of whom are represented as speaking with multiple voices, is a guarantee that otherwise unauthorized behavior, if not legitimate from a religious or legal perspective, is at least worthy of mention. Finally, part of this heteroglossia emerges from the nature of al-Udfuwi's relationship with his subjects. Born and trained in the region but living, as he wrote, in Cairo, al-Udfuwī was writing as the "native informant" for his Cairene audience (the book was dedicated to his teacher Abū Ḥayyān al-Gharnāțī, d. 745/1344). It was necessary, therefore, to portray himself as close to his subjects as possible, which included physical proximity to the body. This intimacy, both physical and intellectual, led to the inclusion of alternative and irregular, even unorthodox principles, dictated by the irreducibility of the lived experience of bodies, people, and communities. Finally, I will discuss the results of al-Udfuwi's work: the successful image of himself as a reliable historian and a faqih with a pedigree tracing back to Ibn Daqīq al-'̄̄d (d. 702/1302).

The approach I am suggesting here is unique, as it is rare for any biographical collection - not just al-Tâalic - to receive attention as a text rather than a data bank. In this regard, Chase Robinson's observation about prosopographical texts is still largely true: "relatively little has been done" to answer "the first order question - how do the texts say what they say?"11 In fact, a recently published study on narrative in Ibn Ḥajar's (d. 852/1449) al-Durar al-Kämina claims to be the first study ever to study "the narrative nature of biographical dictionaries." ${ }^{12}$ It should not be forgotten, however, that the theological and sociological significance of biographical dictionaries, rather than their status as "archives," has long been recognized. George Makdisi argued that the production of Tabaqāt prior to and during the Mamluk period was a sign of the legal madhhab's corporate identity. ${ }^{13} \mathrm{He}$ also wrote a pair of articles on Ash'arism in which he analyzed the use of biographical dictionaries, including al-Subkìs Tabaqāt al-Shäfíiyya, to create "a new image of the Shāfi ite school of law," one "composed of traditionalists and rationalists, a broad-minded school, inclusive of all the religious sciences, especially kaläm, leader among the orthodox schools of law."14 In these studies, Makdisi paved the way for further studies of

\footnotetext{
11 Robinson, Islamic 71.

12 Gharaibeh, Narrative 51.

13 Makdisi, Țabaqāt, 379, 385-6, 392.

14 Makdisi, Ash`arī 60.
} 
the various messages conveyed by biographical dictionaries beyond the "data" they appear to contain.

Moreover, starting in the 1970s, important work was done on the literary aspects of biographical dictionaries, including studies by Hartmut Fahndrich and Fedwa Malti-Douglas..$^{15}$ Whereas Fahndrich studied the "literarization" of Ibn Khallikān's biographical dictionary and the author's literary "style" by comparing anecdotes, Malti-Douglas, in her study of al-Ṣafadìs Nakt al-Himyān $f \imath$ Nukat al-Umyann, showed the importance of paying attention to the thematic emphasis of authors of biographical dictionaries by studying how information is presented in the biographies. One cannot, she argued, "distinguish between purely literary or purely historical effect. A change in one aspect of the text most often represents a change in the other. This is because the Medieval Arabic biographical notice functions as a semiotic system, that is a system of signs."16 Unfortunately, following Malti-Douglas's revealing study of how dreams functioned as signs, no study has been dedicated to the semiotic interpretation of a Mamluk-era biographical dictionary.

The same cannot be said for other historical periods. One significant study which reveals the importance of studying biographies, not just as conveyors of information but as signs, is Michael Cooperson's landmark study Classical Arabic biography, which discusses the use of biography "to document and perpetuate traditions of authority based on knowledge borne and transmitted, or merely claimed, by groups (Tawä'if, sing. TTa $\vec{i} i f a$ of specialized practitioners)." ${ }^{\prime 17}$ An important argument of this study is that biographical dictionaries' "literary effects' arose in response to the need to negotiate crises in the history of the groups whose collective life the biographers had undertaken to record."18 Shocking anecdotes, scandals, and humorous stories all combine to provide an air of veracity to the text. In part, this is a result of biographical writing's liminal position "on the margins of history," which invites commentary and judgment from the author on events usually already known to the intended reader. ${ }^{19}$

Cooperson argues that these judgments and the apparent veracity of marvelous or embarrassing tales often worked to legitimize the professional occupation of the writer. "In the apologetic prefaces they attached to their works, the adab-biographers made explicit what was implicit in Hadith-biography, namely, the notion that professional legitimacy derived from the documented

\footnotetext{
15 Fahndrich, Wafayāt; Compromising; Malti-Douglas, Controversy; Dreams.

16 Malti-Douglas, Dreams 140.

17 Cooperson, Classical, preface xii.

18 Ibid.

19 Ibid. 22-3.
} 
transmission of knowledge." ${ }^{20}$ This judgment would not strictly apply to alUdfuwi, who wrote not of a single $t \bar{a}$ iff but of any important person who was born or spent a considerable amount of time in Upper Egypt. Rather than attempting to ground the authority of a particular profession by linking it to ancient or prophetic knowledge or authority, al-Udfuwi attempted to legitimize his region and the scholars living in and originating from that region by showing that it boasted a wide range of 'ulama $\bar{a}$ and $u d a b \bar{a}$ ' whose authority resided in their training in the madrasas and their work as poets, jurists, scribes, and administrators.

What is al-Udfuwi's vision of historiography, and how does this vision unfold in the text? I propose to answer these questions by beginning with the introduction, or tahmid, which I will show functions as a semiotic sign, recognizable by his medieval audience. The tahmid was considered by Arabic rhetoricians to reflect both the content of the text and the author's intention in writing the text. This occurred not only through directly stating this content and intention but also, as will be described below, through thematic parallelism between the images, themes, and mood of the tahmìd and the proceeding text.

Studies on the tahmìd, also referred to variously as the khuṭa, iftitāh, tașdìr, hamd, or șadr al-kitāb, are very sparse. Only a few studies have given attention to the tahmid, or to use Aziz Qutbuddin's apt translation, the "laudatory preamble."21 The structure of the tahmìd, including the ubiquitous inclusion of the basmala (commencing by invoking God's name), the hamdala (praising God), and the $a m m \bar{a} b a^{\text {c}} d$, were based on developments in the structure of the khutba, or Arabic oration, which were already formulaic by the end of the Umayyad period. ${ }^{22}$ This may explain why the tahmìd, the laudatory preamble, is also sometimes referred to as a khutba. ${ }^{23}$ According to Bilal Orfali, by the gth century, the tahmid had a clear "tripartite structure" composed of the initial basmala and hamdala, then a middle section in which the author states the reason for writing the book and notes the method or sources to be used in the book, and, finally, the laudatory closing statements. ${ }^{24}$ Authors commonly refer

\footnotetext{
20 Cooperson, Classical 7.

21 Qutbuddin, Tahmid 12.

22 Qutbuddin, Khuṭba 206.

23 Ibid. 182.

24 Orfali, Art 182-3.
} 
here to the reasons for writing the book; Peter Freimark notes that common justifications are the request of a person or patron. ${ }^{25}$

Classical Arabic rhetoricians distinguished the khutba as a place of special significance within a literary composition due to its ability to set the tone for the audience and engage their attention. Abū Hilāl's (d. after 400/1010) remarks in his Kitāb al-Sinā'atayn in a chapter on "Beginnings" are exemplary of the high regard for introductory statements. We know that this was a book that alUdfuwi was familiar with since he refers to it in al-Tălic, so his words on the subject are worth quoting here. ${ }^{26}$ According to Abū Hilāl:

Some of the writers have said, "Attend well to your introductions, $\mathrm{O}$ writers, for they are the signs of eloquence (daläil al-bayān)." They said, "The poet must avoid in his poetry and in commencing his speech what can be taken as an inauspicious sign, what provokes tears and aversion to words and discourse by describing desolate homes and the dispersion of communities, mourning the youth and disparaging time, especially in poems whose subject is praise and felicitations." ${ }^{27}$

While the section above refers directly to poetry, the literary standard of husn al-ibtid $\bar{a}$, recognized as a form of aesthetic eloquence since the development of Arabic poetics by Ibn al-Mu'tazz (d. 296/908) as a distinct discourse, was extended to prose as well. ${ }^{28}$ Whereas Abu Hilāl is laconic about the importance of appropriate introductions, preferring rather to cite dozens of examples of successful introductions, Ibn al-Athīr (d. 637/1239), in his Mathal al-Säir, expands on the topic, noting explicitly the importance of introductions for both poetry and prose:

The Twenty-Eighth Device: On Preambles and Beginnings

The truth about this type (of rhetorical device) is that it makes the commencement of one's speech, whether in poetry or epistles, indicative of the intended purpose of the speech. So, if it is (for the occasion of) a victory, then it should be triumphant, if for congratulations, then congratulatory, and if for condolence, then consoling. Such is the case as well for other purposes besides these. The benefit of this is to make known from the start of one's speech what is intended by it, and why it takes this form.

Freimark, Vorwort $35 \mathrm{ff}$.

Al-Udfuwī, Țālic 34 .

Al-'Askarī, Șinā'atayn 431.

28 Ibn al-Mu'tazz, Badī' $103-5$ 
The fundamental axiom of this is that it is obligatory for the poet when he composes a poem to consider the following: If it is a pure encomium, not written on the occasion of a particular event, then he must choose between commencing it with amatory verse (ghazal) or, if he does not use amatory verse, to commence immediately with the laudatory verse ... But if the poem is written on the occasion of a particular event like the capture of a fortress, the defeat of an army, or something else, then he must not commence with laudatory verse. If he does this, it indicates the poor temperament of the poet and his inability to hit his mark, or, his ignorance of how to place speech in its (proper) order ...

The correct custom for this type is for the poet to avoid commencing a laudatory ode with something that is considered a bad omen. This is based on the adab of the soul, not the adab of learning. So, he must be wary of doing this on certain occasions, such as describing abandoned homes and encampments which have vanished ... We have specified beginnings here because they are the first things to ring in one's ears. Therefore, if the beginning is appropriate to the following content, then reasons exist for listening. It is enough to mention here the beginnings found in the Quran, such as the laudations which the first parts of the süras commence with, as well as the supplicatory beginnings, such as God's words at the beginning of Sürat al-Nisa ...

The same can be said for beginning with letters, such as God's saying: "aliflām wa-ța-sin wa-hâa-mīm" and the others like this, for those also direct one's hearing to it, for it strikes the ears as something strange, something completely unaccustomed, which is a cause for one to pay attention to it and listen. ${ }^{29}$

In another section of the Mathal al-Säir, Ibn al-Athīr writes that "speech is commenced with giving thanks because the soul yearns to show gratitude to God, and commencing with what the soul yearns for is what is sought."30 This literary standard, husn al-ibtid $\bar{a}^{\prime}$ or $b a r a \bar{a}^{\prime} a t ~ a l-i s t i h l \bar{a} l$, was applied equally to both poetry and prose. ${ }^{31}$ Key to its success was ensuring that the beginning actually reflected the contents of whatever followed. As seen above, a partic-

29 Ibn al-Athīr, Mathal i, 96-8.

$30 \quad$ Al-'Askarī, Șinā́atayn 276; also quoted in al-Qalqashandī, Subḥ vi, 225.

31 Safî l-Dīn al-Ḥillī and Abu Hayyān al-Gharnāțī, however, also refer to it as "barā'at almatla,", al-Ḥillī, Sharḥ 57-9; al-Gharnāțī, Baḥr i, 152. 
ularly grave mistake, discussed by both al-'Askarī and Ibn al-Athīr, was to commence with something that could be taken as a bad omen, such as mentioning the at la $\bar{l}$ l or lamenting time on a joyous occasion. We should, therefore, expect that the tahmid matches the purpose and content of the book. To have this resonance was not simply ideal in an aesthetic sense; it was a sign that could direct the mood of the reader toward what the writer intended and motivate him or her to react to the following speech in a particular way.

Finally, it should be pointed out that the Quran was, possibly more so for the laudatory prelude than in other aspects of $a d a b$, considered paradigmatic in this regard. According to al-Qalqashandī (d. 821/1418), the order of the khut ba, in which the doxology comes directly after the invocation of Allāh's name, is based directly on the model of the Fâtiha. ${ }^{32}$ Epistles that do not begin with the doxology, on the other hand, are a reflection of the insignificance that the author attached to the subject at hand. ${ }^{33}$ The trick to a successful khut ba, which displayed barāat al-istihläl, was to convey a hint of one's intentions while conforming to the Quranic model..$^{34}$ Hence, the doxology was a highly symbolic field within the literary text, and the way in which a person expressed praise to God was expected to indicate their motivation for writing while directing the expectations of the audience to a particular theme. If we look at al-Udfuwi's tahmìd, we see:

In the Name of God the Merciful, the Beneficent:

Praise be to God, Reviver of decaying bones, Rejuvenator of what has passed in days of yore. I praise Him for His successive blessings, one following the other, and I thank Him for making me one of the carriers of ilm, for those who carry it are people of the highest ranks. I give perpetual salutations, unending until the Day of Judgment, to the Prophet sent as a mercy to the universe and a testimony for the pious, and to his companions, who transmitted his path and preserved his way for us. They are among the winners in the world to come.

Al-ḥamd li-llāh muhyȳ l-rimam al-bāliya wa-nāshir mā-anțawā fì l-ayyām al-khāliya. Aḥmaduh 'alā ni'amih al-mutarādifa al-mutawāliyya waashkuruh 'an ja'alanì min hamalat al-ilm wa-hamalatuh hum ahl al-rutab al-āliya wa-uṣallì 'alā nabiyyih al-mab'üth raḥmatan lil-älamìn șalätan

32 Al-Qalqashandī, Subḥ vi, 225.

33 Ibid.

34 Ibid. 
muttașila dā̉ima ilā yawm al-dīn wa-'alā àlih wa-aṣhābih alladhìn naqalū ilaynā wa-hafazū sharīatah 'alaynā fa-hum fì l-äkhira min al-fä̀izìn.

Considered in isolation, this is a standard introduction that many modern readers may well skip or skim to get to the "content" of the text. Yet, this would be a mistake for two reasons: First, al-Udfuwī and his teacher, Abū Hayyān, reveal in their writings that they considered the khutba of other writers to be a sign of the literary talents of the writer. ${ }^{35}$ In light of this emphasis both place on the khutbas of others, it is fair to assume that they-the author and the dedicateewould likewise approach the khuțba of al-Tälic with high expectations. Second, compared to the literary standards of his age, we can see that this introduction is a semiotic sign that al-Udfuwi modeled his vision of historiography on the divine resurrection and final accounting. He does this, moreover, by imitating God, as we will see shortly.

Following the initial tahmīd, al-Udfuwi immediately begins listing the reasons that history, in general, is "a necessary craft ( fann)": It provides knowledge about prior generations and reveals who is deserving of praise and who is "more undeserving than a thread." This general description of the purpose of history is the only part of al-Udfuwi's introduction to have caught the attention of modern scholarship; it was translated by Franz Rosenthal in his History of Arab historiography. ${ }^{36}$ But he did not quote the all-important initial section, so vital as we saw above for signaling the purpose of the text, nor did he focus on what comes next, which reaffirms the significance of the initial thematic.

After this general statement on the purpose of history, al-Udfuwi describes his reasons for writing about Upper Egypt-it is his birthplace, where he was raised and educated, and where he grew old. He then quotes a poem he wrote describing his yearning for the land. Up to this point, nothing is surprising. It is what follows that is remarkable:

I wanted to resurrect that which had passed away from the knowledge of Upper Egypt's scholars, to spread (anshur) the excellence of its notables, to manifest what was hidden among the prose of its rhetoricians and what had disappeared from among the verse of its poets, and to relate what had been forgotten about the virtues of its virtuous people and the nobility of its upright individuals, for a person is honored by the honor of his people, just as he is elevated by their nobility and excellence.

35 Al-Udfuwī, al-Ṭāli 587; al-Gharnāțī, Baḥr i, 112.

36 Rosenthal, Muslim 307. 
fa-ahbabt an uhȳ mā māt min 'ilm 'ulamāihà wa-anshur min faḍl fudaläihā wa-uzhir mā khafiya min nathr bulighä̉ihà wa-daras min nazm shu'arāihā wa-adhkur mā nasiya min makārim kuramāihā wa-karāmat șulahăàihā fa-l-insān yukram bi-kirāmat ahlihi kamā ya zum bi-nublih wafadlih.

What al-Udfuwī has done here is to model his action of writing history on characteristics he attributes to Allāh in the opening tahmìd. Due to the repetition of words, the parallel structure, and the proximity of the two statements, this act of imitation is unmistakable. Just as God resurrects human beings-in their entirety and regardless of their virtue-in order to be judged, so al-Udfuwi will resurrect the knowledge ( $\mathrm{ilm}$ ) of the scholars to "spread" it. Key to understanding this passage is the word anshur, which constitutes a tawriyya or double entendre in which two meanings-one expected (qarïb) and the other unexpected (baid) - are present to the mind, the reader unable to decide between them but for the existence of a piece of contextual evidence (qarina) that indicates the unexpected meaning. ${ }^{37}$ While I have chosen above to translate anshur as "spread" in order to highlight the dual meaning of the word, there is a clear qaina that indicates the unexpected meaning of "resurrect." This qarina is the parallel structure within the $k h u t b a$, linking the divine resurrection to the resurrection of knowledge through memory. The effect of this parallelism is twofold. On the one hand, it authorizes a recording of the biographies of a large number of contemporary individuals, some of whom, as we will see, are remembered for their heterodox beliefs or practices. On the other hand, it extends the promise of a verisimilitude like that of God's resurrection for judgment; reviving the dead is not an act of creativity, but rather one that reproduces the past within the present exactly as it was. This implies, of course, recollecting vices as well as virtues.

In his khuṭba, al-Udfuwī imitates God both in speech and, metaphorically, in action. In terms of speech, the praise of God as the reviver of dead bones and of what has passed before (muhyi l-rimam al-bāliyya wa-nāshir mā-anțawā fì l-ayyām al-khāliyya), along with its parallel structure to al-Udfuwīs descrip- 
tion of his historiographical undertaking, allude to Quranic passages. ${ }^{38}$ Quoting or alluding to Quranic passages, often referred to as iqtibās al-Qur'ān, was, of course, a common and widely accepted literary practice. ${ }^{39}$ Moreover, alUdfuwīs mentor, al-Gharnātî, was a proponent of the philological approach to the Quran, according to which the Quran is an "open text": Its meaning is not limited to what is understood by its initial audience, but it continues to reveal new meanings to each generation of Muslims who could apply literary standards to the text to appreciate its eloquence and message. Literary standards, according to this school of thought, were equally applicable to adab and scripture; all language, even God's, existed on a continuum. In fact, it was the ability to apply aesthetic standards to both the Quran and adab that allowed one to fully appreciate the miraculous inimitability of the Quran (ijjaz al-qurān $).{ }^{40}$

More controversial, however, is the imitation-even if metaphoric - of God's action. After all, from one perspective, nothing seems more fundamental to Islamic orthodoxy than the idea that the God of the Muslims is a God totally unlike His creation. "Nothing is like unto Him (laysa ka-mithlih shay')."11 Possibly because of statements like this, modern scholarship on Islam reveals a very poor understanding of the importance of the concept of the imitation of God, or imitatio Dei, in premodern Islamic thought. In fact, several modern scholars, including the eminent S.D. Goitein, have made the case that Islam is characterized by a tendency to imitate the Prophet Muhammad to the exclusion of God. ${ }^{42}$ According to this perspective, there is no such thing in Islam as the imitation of God, or the imitatio Dei, or if such a concept did exist, it only played a minor role. This characterization of Muslim traditions blinds us from recognizing the symbolic import of the imitation of God's speech, the Quran, and God's characteristics. If we take this approach, we put ourselves in the unenviable position of completely missing the importance of metaphoric descriptions of human activity based on God's characteristics, such as the one that frames al-Udfuwì's biographical dictionary.

Before examining this concept in the context of al-Udfuwi's text, I should say something about this concept of the "imitation of God." In a non-Islamic

$38 \quad$ Q 2:28, 78, 243, 258-9; 3:156; 7:158; 8:24, 42; 9:116; 10:56; 22:6, 66; 30:51; 41:39; 36:78-9; 53:44; 80:21-2.

39 Orfali and Pomerantz, Distant 192-7.

40 Al-Gharnațī, Bahr i, 109-11; see also Saleh, Ibn Taymiyya for a discussion of the philological approach to tafsir.

$41 \quad$ Q 42:11.

42 Goitein, Studies 22n2. See also the similar assumptions expressed in Riexinger, Rendering $103-4$. 
context, the term is often used to refer to one of two things. First, in Greek philosophy, it can refer to the idea that all creation strives to achieve its own perfection by approaching the Unmoved Mover. Second, and more commonly, it refers to the Biblical idea, found in both Leviticus and the First Epistle of Peter, that one should be holy as God is holy. Imitating God, al-tashabbuh billāh was not by any means foreign to medieval Islamic thought. In the early 14th century when al-Udfuwi was writing, however, it was at times associated by Sunni thinkers with the faläsifa, as we learn from Ibn Taymiyya's writings, which reject the notion as "more evil than the shirk of the Arab polytheists," because its proponents purport to bridge the ontological gap between God and his creation. ${ }^{43}$ At the heart of the disagreement over the imitation of God was the ambivalent nature of God's attributes in relation to his creation. On the one hand, God is totally unlike his creation in essence and attributes. This was emphasized by al-Qurțubī (d. 671/1272) in his commentary on the laysa kamithlih shay' verse:

The belief regarding this topic is that God, magnificent of name, in His greatness, His might, His sovereignty, the beauty of His names and exaltedness of His attributes, resembles nothing (la yushbih shay'an) from among His creations nor can He be made to resemble them. Indeed, this is part of what the Law determines regarding the Creator and His creation: there is no similarity between them in reality because the attributes of the Eternal are incommensurable with the attributes of His creation. Created beings are ensnared in end-purposes ( $a g h r a \bar{d} d)$ and accidents ( $\left.a^{\prime} r \bar{a} \underline{d}\right)$ ), but He the Sublime is above that. Rather, He perdures with His names and attributes as we made clear in al-Kitāb al-Asnā fi Sharh Asmä Allāh alHusnā. The statement of God suffices here: "Nothing is like unto him."44

On the other hand, God ascribes to Himself attributes that are also used to describe humans and other created things, and it is by understanding God through these attributes that one can acquire the knowledge of Him required of all Muslims. This is true even of the word shay' itself, which, of course, can be applied to anything, as al-Qurțubi writes in his book on the names of God, mentioned in the preceding quote. Is it tashbih to call God a shay'? According to al-Qurțubì, drawing this conclusion would mean that a person could not talk about God at all: "That would necessitate that the Creator not be described

43 Ibn Taymiyya, Șafadiyya 347.

44 Al-Qurțubī, al-jāmic xviii, 45o. 
as One or as existing, for other things share with him oneness and existence." Sharing a name is not the same thing as sharing an essence. ${ }^{45}$

The problem, of course, with this solution is that the names were more than empty signs; to say that God is a "thing" (or Merciful, Revivor, or any other attribute) is to connotate something, not just denote a class of objects. ${ }^{46}$ And, indeed, we see al-Qurțubi in his book on the Divine names describe the proper behavior that names of God instill in the believer. For example, knowing that God is almighty ('azim) leads to abasing oneself in the face of this might. ${ }^{47}$ But for other Sunni writers, including al-Qushayrì (d. 465/1072), alGhazāīi (d. 505/1111), Ibn al-'Arabī (d. 638/1240), and al-'Izz b. 'Abd al-Salām (d. 66o/1262), knowing God's names and attributes did not just produce in humans a certain deportment toward God but, ideally, should also lead to the acquiring of these characteristics: al-takhalluq bi-akhlāq allāh. These writers, to various extents, saw the names of God as a model for believers who wished to shed their baser, sublunar characteristics, and associate with the Divine. ${ }^{48}$ For al-Ghazālī, all God's attributes could be imitated by the believer; some, however, such as those related to His ability to create, could only be imitated metaphorically. ${ }^{49}$ Like the Stoics, these writers saw true happiness as occurring only once someone had shed their baser attributes and acquired divine characteristics through self-discipline. ${ }^{50}$ According to Ibn 'Abd al-Salām, in addition to names referring to attributes which should be imitated, there are some attributes that cannot be imitated, such as God's eternity, whereas others, such as God's might, should not be imitated by a human (although it is possible). ${ }^{51}$ Unlike these writers, Ibn al-'Arabī saw all the names of God as potential attributes of human beings; in fact, for Ibn al-'Arabī, being human is exactly this potentiality of acquiring the Divine names latent in each human. ${ }^{22}$

It should be clear by now that imitating God in the form of al-takhalluq bi-asmä alläh or al-takhalluq bi-akhlāq allāh was a common, widely accepted concept by the time al-Udfuwi was born in the mid-13th century. It is true that

$45 \quad$ Ibid., Asnā 91.

46 For the use of the words "denotation" and "connotation" in reference to the Divine Names, see Shahzad, Ibn 'Arabī's 14.

47 Al-Qurțubī, Asnā 18o.

48 Al-Qushayrī, al-Risāla 148-5o; al-Qushayrī, 263-5; Al-Ghazālī, Maqșad; Ibn 'Abd al-Salām, Shajarat $53-95$.

49 Al-Ghazālī, Maqșad 83-4.

50 For the relationship between the concept of al-takhalluq bi-akhlāq allāh and Stoicism, see Groff, Kindī 145-6.

$51 \quad$ Ibn 'Abd al-Salām, Shajarat 53.

$5^{2}$ Chittick, Sufi 274. 
all of the thinkers cited above were Sufis of one kind or another. Yet, so was alUdfuwī, and al-Ghazālī and Ibn 'Abd al-Salām were also highly respected Shāfi'ī jurists. The latter, in particular, had an important role in shaping al-Udfuwis own scholarly milieu, as several of his teachers studied with Ibn 'Abd al-Salām's students. ${ }^{53}$

The idea that imitating God, rather than the ideal man, Muhammad, is some kind of mutation of orthodox Islamic theology is not just a modern projection onto the past; there were some criticisms of this view. According to Ibn Taymiyya (d. 728/1328), one can only affirm the existence of names and attributes shared between God and His creation to the extent that they are mentioned in scripture, such as "He is beautiful, and He loves beauty" 54 By interpolating foreign concepts into Islamic belief, however, Ibn Taymiyya thought that Sunni scholars had violated the fundamental otherness of God:

This was rejected by some people like Abū Hâamid al-Ghazālī, among others, and they made it so that the servant (al-'abd) could be described as "the imperious (al-jabbār)" and "the insolent (al-mutakabbir)" according to some explanation of theirs. Then they called all of that "acquiring the characteristics of God (al-takhalluq bi-akhlāq allāh)," citing as a hadith, "Acquire the characteristics of God." Others, like Abū 'Abdallāh al-Māzarī and some others, censured them for this. They argued that the Lord has no "characteristic (khuluq)" that the servant acquires, and they said, "this is philosophy draped in the garment of Islam." What they meant was the saying of the philosophers: "philosophy is imitating god to the extent of one's ability." 55

Ever the clever polemicist, Ibn Taymiyya associated the widely accepted views on imitating God with the mutafalsifa. Nevertheless, to accept this characterization as a general description of Islamic orthodoxy in the early 14th century would be to ignore the flourishing of the concept of the imitation of God, which, as we just saw, was actually embraced by Sunni fuqah $\bar{a}$ ' of the highest standing. If the imitation of God as an ethical concept was embraced by main-

53 Al-Udfuwī mentioned al-'Izz as the teacher or judicial superior of the individuals in biographies number 43, 231, 277, 404, 405, 463, 480, and 587. These individuals included the illustrious Taqī al-Dīn b. Daqīq al-'̄d (see below) and the father and mentor of Tāj alDīn al-Dishnāwī, whose study circle al-Udfuwī attended for a number of years. Al-Udfuwī eventually received an ijāza from him. See al-Udfuwī, Țālic $488-97$.

54 Ibn Taymiyya, Radd 96.

55 Ibid. 145 . 
stream Sunni writers, it was not just an ethical or philosophical concept. In practice, it could take the shape of an art form, since, as al-Ghazāli wrote, all of God's characteristics could be metaphorically imitated. Such a practice was exactly what a skilled Arabic writer could do to invoke the Divine to embellish and elevate their ideas, and it is what we saw al-Udfuwi do above by inserting the metaphoric imitation of God into the laudatory preamble. We should, then, take al-Udfuwi's claim to model his writing on God's resurrection seriously. It is a claim to objectivity. Just as God resurrects people, exactly as they were, with all of their faults and weaknesses to be judged, so would al-Udfuwi resurrect the work and scholarship of the Upper Egyptians, along with all the heterogeneous traditions and human variance this implies.

We should not be fooled by this claim to objectivity. Al-Udfuwī had an agenda, and the semiotic equivalence of historiography with resurrection was a crafty way to both obscure and achieve this aim. What I will show now is that this appearance of objectivity, authorized by al-Udfuwi's representation of history as an imitation of God's resurrection, led to a radical destabilization of orthodoxy and a simultaneous attempt to show that Upper Egypt hosted Sunni scholars, luminous grammarians, and talented poets. This was no easy task. Upper Egypt in the century prior to al-Udfuwì's death was wracked by violent uprisings. ${ }^{56}$ Many of these uprisings had pro-Fatimid loyalties. Moreover, several members of his own family were well-known Shici supporters, something he could hardly hide in his biographies without being accused of blatant obfuscation of the truth. One of his cousins had even sworn an oath of allegiance at a public ceremony to the 'Ādid pretender, Dāūud, who appeared in Upper Egypt in 697/1298. In fact, al-Udfuwī himself had attended this ceremony. ${ }^{57}$ Upper Egypt, moreover, still had a large Christian population. ${ }^{58}$ However, apart from a few references to converted Christians, one small notice denying the role of the Sufi shaykh Ibn Nūh in the destruction of several churches in Qūṣ, and a generic Sufi description of enchantment by a Christian youth, the Christians of Upper Egypt are entirely overlooked..$^{59}$ Al-Udfuwī only includes biograph-

\footnotetext{
$5^{6}$ Garcin, Centre 128-31, 183-6, 368-74, 379-84.

57 Al-Udfuwī, Țālic 66, 368; Daftary, Ismāî̀ìis 254; Stern, Succession 211.

58 Hofer, Popularisation $184-5$.

59 Al-Udfuwī, al-Ṭălic biographies number 306, 328, 331, and 470. See el-Leithy, Sufis for a discussion of al-Udfuwì's portrayal of Ibn Nūḥ's purported role in the destruction of 13
} 
ical entries on Muslims, and the consequence of this decision is that Christians are completely marginalized so as to pose no threat to the positive, thoroughly Muslim image of the region. ${ }^{60}$

Thus, the way al-Udfuwi portrayed his region as a bastion of Sunni orthodoxy was not through any form of forgery but through selective reporting. The Shi $i$ past is almost entirely eradicated from his biographers, as is the record of the pro-Fatimid revolutions. For example, al-Udfuwi provides no biography of the Banū l-Kanz or their various leaders who went by the title "Kanz al-Dawla," and there is only one brief, offhand reference to the revolt of the Jacafira in 650/1252$3 \cdot{ }^{61}$ Nevertheless, the Banū Kanz do make regular appearances in the text as the subject of praise poetry composed by Upper Egyptians. ${ }^{62}$ Without previous knowledge of the Banū Kanz, one would never know that these individuals played a controversial part in Upper Egypt's history. Thus, in the biography of 'Alī b. Muhammad Ibn al-Naḍr, qậ̣̂̀ l-quḍāt in Aswan and Ikhmìm during the vizierate of al-Afḍal Shāhanshāh (r. 1094-1121), it is mentioned that he wrote in praise of the Banū Kanz until they removed him from Aswan. ${ }^{63}$

This is what makes al-Udfuwis biographies of his own family of such interest to the historian. It is clear that his family had a long history of leadership within his native town of Udfü. The oldest ancestor in the book, Nawfal b. Jaffar (d. 572/1177), whom al-Udfuwì calls "our most senior forefather," was the häkim (a judge or arbitrator) of Udfū and 'Aydhāb, and al-Udfuwī says he was informed

churches. El-Leithy calls al-Udfuwī the "partisan" of Ibn Nūh, although there is little evidence for this besides al-Udfuwī's inclusion of Ibn Nūḥ in his history. Regardless, el-Leithy notes that Upper Egyptians, like al-Udfuwi, may not have had the same motivation as urban writers living in Cairo to attribute mob violence against Christians to Ibn Nūh, who was, in fact, prosecuted by the Mamluk authorities for the church destruction. Ibid. n228. But cf. Hofer, Popularisation 216-7, who argues that Ibn Nūh was likely the instigator of this revolt.

6o Sometimes the appearance of Christians in al-Udfuwi's history appears to serve the sole purpose of disarming his readers' fears about Christian strength in the region and in the administration. See, in this regard, the anecdote about Majd al-Dīn b. Daqīq al-Īd, who insists, despite his disciple's warnings, on visiting the house of a Christian tax collector in order to ask the latter for tax alleviation for a Muslim ascetic, only to find the Christian tax collector rushing, barefoot, to greet Majd al-Dīn and assure him that he will always come attend to Majd al-Dīn should he only ask. Al-Udfuwī, Țālic 329 .

61 Ibid. 504; For the Banū l-Kanz, see Garcin, Centre 126-9, 366-79, 383, 392-5, 405; Holt, Kanz; Rapoport, Invisible 2. For the Jacafira, see Garcin, Centre 362; and Rapoport, Invisible $14-6$.

62 See al-Udfuwī, Taălic biographies number 66, 69, 127, 183, 199, 206, 316, 415, 459, 462, and 585 .

63 Al-Udfuwī, Țālic $408-14$. 
that he had this position for over 40 years. ${ }^{64}$ One of his sons, Mufaddal, was also hăkim for some unspecified period. ${ }^{65}$ His nephew, Thalab b. Ahmad (d. ca. 640), is mentioned as a ra'ss and hăkim in Udfū for a period of some years. He also corresponded with the fourth Ayyubid sultan of Egypt, al-Malik al-Kāmil Nāșir al-Dīn (d. 635/1238), and the latter's letter was still in the family's possession. ${ }^{66}$ After Tha'lab, the position of hăkim seems to have been transmitted to the grandson of Nawfal, his namesake Nawfal b. Muțahhar (d. 657/1258-9), about whom al-Udfuwī only mentions that he was a wealthy yet stingy man, which is why Ibn Shams al-Khilāfa wrote satirical poetry about him. ${ }^{67}$ We also learn from the biography of his brother, 'Alī b. Muțahhar (d. ca. 65o/1252-3), who was al-Udfuwì's great-grandfather, that Nawfal preferred to have 'Alì meet with people in his stead. ${ }^{68}$ After Nawfal b. Muțahhar, the next häkim was his paternal cousin, 'Alī b. Tha'lab (d. ca. 66o/1261-2). At this point, al-Udfuwì no longer seems to be relying on community and family memories for his information, for he says that he was able to read 'Alì's taqlìd, written by Diyä' al-Dīn Ja'far al-Qinā̄ī, who was a student of Majd al-Dīn al-Qushayrī (d. 667/1268) and a teacher of al-Udfuwì's mentor, Abū Ḥayyān al-Gharnāțī. ${ }^{69}$ At this point, the position of hăkim appears to have left the family. After this generation, alUdfuwīs family filled less prominent positions as shähid (notary) and khațīb (preacher). Still, even these individuals appear to have faced increasing resistance from the urban class of scholars and jurists, despite apparently enjoying popularity in their hometown. ${ }^{70}$

Why this change in the family's fortunes after the generation of al-Udfuwi's great-grandfather? It is hard to escape the conclusion that this was a result of the family's long-lasting association with two (related) intellectual traditions which were irrelevant and suspicious to the growing class of Upper Egyptian urban scholars and jurists: Shi'ism and the "ancient sciences" (al-ulüm al-qadima), including medicine, philosophy, and music. The family were specialists in these fields; out of the 14 agnates al-Udfuwī included in the Tă $l i{ }^{\prime}$, half of them are identified as having expertise in the 'ulüm al-qadìma (see figure 1). These 'ulüm were likely transmitted within the family. Al-Udfuwī states explicitly that his uncle Muhadhdhab b. Jaffar learned the 'ulüm al-qadìma from

\begin{tabular}{ll}
\hline 64 & Ibid. 684-5. \\
65 & Ibid. 417. \\
66 & Ibid. 176. \\
67 & Ibid. 685. \\
68 & Ibid. 416-7. \\
69 & Ibid. 182, 381-2. \\
70 & Ibid. 662.
\end{tabular}


the latter's great-uncle, Jaffar b. Muțahhar, and al-Udfuwī read Muhammad alHusayn's writings on Sufism and falsafa. Moreover, the town of Udfü was home to other experts in these sciences, such as the 6th/12th-century scholars Șakhr b. Wāill and Zuhayr al-Udfuwī, indicating that the area was likely a locus for the study of the 'ulūm al-qadìma. ${ }^{11}$

Indeed it was only around the generation of al-Udfuwìs great-grandfather that the major sources of resurgent Sunnism, particularly the Najibiyya madrasa and the Shāfi î scholars and texts so fundamental to the teaching curriculum, appeared in Qūṣ and its environs. The Najībiyya madrasa, which al-Udfuwi describes as the "the origin of good (așlal-khayr)" was only built in 607/1210. ${ }^{72}$ Shortly thereafter, Majd al-Din al-Qushayrī, the father of Taqī al-Dīn Ibn Daqīq al-Īd, was invited to move to Qūṣ to teach in the new madrasa. It was Majd al-Dīn, al-Udfuwī writes, who "brought the madhhab of the sunna to the region" at a time when "the madhhab of the Shi'a was ubiquitous."73 If, following Garcin's analysis, we take the arrival of Nāșir Ibn Abī l-Futūh (d. 565/1169), the companion of the highly respected Alexandrian muhaddith al-Silafì (d. 576/1180), as the region's first, gentle nudge toward "la contreréforme sunnite," we can see that the generation of Nawfal b. Ja far and his sons was still living in a milieu relatively untouched by the reform movement, but that the generation of al-Udfuwi's great-grandfather was, indeed, the tipping point in the struggle for the sectarian identity of the region's Muslims. ${ }^{74}$ This analysis confirms Tamer el-Leithy's observation of an "emerging fragmentation of Upper Egyptian society" in the early 14th century due to the increasing Islamization of the region, the influx of outsiders, particularly Maghrebis and Sufis, and the repeated violence between Mamluk authorities and Bedouin. ${ }^{75} \mathrm{We}$ can add that, from the perspective of local notables like al-Udfuwi's family, this fragmentation was also a result of the increasing oversight of the judiciary from Cairo, which forced individuals to assume the identity of a madrasa-educated, Sunni Muslim in order to gain access to these positions. ${ }^{76}$

$71 \quad$ Al-Udfuwī, Țālic 251, 270.

72 Ibid. 408; Garcin, Centre 173.

73 Al-Udfuwi, Țălic 424.

74 Garcin, Centre 158-9; al-Udfuwī, Țālic $671-2$.

75 El-Leithy, Sufis 86, 105-7, 118.

76 When the Chief Qāḍi b. 'Abd al-Salām ordered that all subordinate judges in the provinces be Shāfi $\overline{1}$, judges in Upper Egypt who had not received enough training in figh in the madrasas needed to receive special permission to continue in their positions: al-Udfuwī, Taăli‘ 632 . See also 'Abd al-Malik b. Ahmad al-Armantî's acerbic verse on the ills of the working as a notary in the sūq al-wirāqa, which leads to thinking poorly of everyone, produces 
In the midst of this social turmoil, why did al-Udfuwi decide to include his Shi $\mathrm{i}$, heterodox past in his history of Upper Egypt? As noted above, this is probably in part due to the fact that al-Udfuwī could not hide his Shi'i heritage, given the prominence of his family. Yet, it is curious that al-Udfuwi includes no biography of his father. This may be because al-Udfuwī, as we learn in another place in his biography, was orphaned before completing his education. In fact, it may be because of his father's premature death that he was able to integrate so successfully into the dominant Sunni-madrasa culture of his time. Al-Udfuwi relates in his biography of Yūsuf b. Muhammad al-Suyūṭi that, when the latter was appointed $q \bar{a} d \bar{l} \bar{\imath}$ of Udfū, al-Udfuwī finished studying al-Shīrāzì's al-Tanbīh under him. At the time, al-Udfuwī was an orphan under legal interdiction (taht al-hajr), and al-Suyūțī, exercising his prerogative as a judge to supervise the wealth and welfare of orphans, decided to increase al-Udfuwi's stipend and send him to Qūṣ for advanced study. It is clear from al-Udfuwīs narration of these events that it was a pivotal period in his life. We know from his biographers that he was eventually appointed as muid (an academic position similar to today's teaching assistant) in Cairo in the prestigious Madrasa al-Ṣāliḥiyya and even held a professorship of hadìth in the Jankalī b. al-Bābā mosque for a short time before his death. ${ }^{77}$

In light of this transformation in al-Udfuwì's fortunes, describing his family's heterodoxy in such clear terms is, far from a surprising incorporation of shameful personal history, a brilliant narrative strategy. On the one hand, as noted above, including strange, shocking, or scurrilous information is a useful way of increasing the reality of the history related. Perhaps more interesting from a historiographical perspective, on the other hand, is that al-Udfuwi in his narration of these events, rather than casting doubt in the reader about his orthodoxy, abolishes any such suspicions by placing himself as an authority on correct belief. Consider, for example, the following selection from his entry on his paternal uncle, an Isma'ili faqīh and faylasüf, 'Abd al-Qādir b. Muhadhdhab al-Udfuwī:

He believed in the Prophet, peace and blessings upon him, and recognized his position. He believed in the obligatoriness of the Pillars of Islam, although he thought that they are no longer required of someone who obtains knowledge of his Lord, on the basis of reasons he believed in.

a crude disposition prone to litigiousness and envy, and the breaking of familial bonds. Ibid. 340-1. 
Despite this, he persisted in praying regularly, both in private and in public, and in fasting, but he only fasted according to what his own reckoning required. He thought that performing legal obligations (al-takālīf al-shariyya) necessarily entails an increase in benefit, even if one has knowledge (of God). He used to think for a long time and get up and dance, saying:

What a tragedy for one to waste their life on what's allowed He'll miss the Here and After too, the fool.

He got sick, and I did not visit him. He died, and I did not pray for him. He has gone now to the graveyard, and he is with Him who knows that which is invisible to the eye and hidden in the heart.

The passage leaves us with the feeling that al-Udfuwi knows the most intimate details about his uncle and seems to have spent a considerable amount of time with him, but we are also assured that al-Udfuwī has dissociated from his uncle, even refusing to visit him on his deathbed or even pray at his funeral. Nevertheless, at the end of this exercise in certainty, we are left with real doubts about the true beliefs of his uncle, knowledge of which is only available to God. We see in passages like these that al-Udfuwī, a liminal figure who often traveled between provincial and political centers and who was genealogically on the cuff of Sunnism and Shi ism, manages, to use Auerbach's words, to portray himself with "the most intense subjectivity" as an objective, reasonable observer, and critic of sectarian identity and belief. ${ }^{78} \mathrm{He}$ manages this, moreover, by describing with the utmost intimacy and clarity, a picture of these very heterodox beliefs that never draws suspicion to his own beliefs but still invites a considerable amount of ambiguity as to the damnability of his subjects.

If there is a clear bias in the selection of biographies, the Țâlic is still not a mouthpiece of any particular consciousness or worldview. Rather, it is characterized by heteroglossia, the Bakhtinian notion of multiple voices and registers grounded in different group practices and ideologies. According to Bakhtin, heteroglossia is a general feature of all discourse: speech is always directed toward an "Other" and expects a response. Moreover, language, always directed toward its "object," struggles both to contain this object and project its repres-

$7^{8}$ Auerbach, Mimesis 27 . 
entation to the Other as legitimate. As a result, "neutral" language has no existence; "[a]ll words have the 'taste' of a profession, a genre, a tendency, a party, a particular work, a particular person, a generation, an age group, the day, and hour." ${ }^{\prime 9}$ Even highly purposeful, intentional speech is not one's "own" but rather carries the traces of other speech, appropriated and retransmitted according to one's situation. Hence, repeated speech, even verbatim quotation, is "always subject to certain semantic changes." During a person's upbringing, assimilation of others' discourses produces "authoritative discourse," that is, "internally persuasive discourse" with which the individual enters into a dialogic relationship. ${ }^{80}$ Even this relationship to authoritative discourse, shot through with various tendencies toward different positions and ideologies, is semantically open: "in each of the new contexts that dialogize it, this discourse is able to reveal ever new ways to mean." ${ }^{81}$ Individuals, constantly balancing competing discourses, are always in a struggle between dialogized utterances. ${ }^{82}$ As a result, speech is never fully one's own, and even apparently authoritarian statements, such as an official decree, is in dialogue with other ideas; speech is always dialogic to some degree. However, there are certain kinds of literature that express heteroglossia to a greater extent than others, such as novels, which place variant worldviews against one another, producing a struggle in which each voice attempts to establish itself against the demands of the other. ${ }^{83}$ In addition to the ubiquitous heteroglossia found in any text, the Țălic exhibits special features of heteroglossia, which can be seen in the following examples.

First, al-Udfuwī was part of a group of historians, poets, and 'ulamä' who valued entertaining stories for their own sake. This group included the well-known poet and $r \bar{a} w \bar{\imath}$ al-Fath Ibn Sayyid al-Nās (d. 734/1334) and the grammarian, muhaddith, and exegete, Abū Ḥayyān al-Gharnāṭ̂̄. Al-Udfuwī dedicated al-Tāalic to Abū Ḥayyān, and he is one of al-Udfuwī's primary sources for poetry, hadīth, and anecdotes about the 'ulamä. In this world, comedic and frivolous stories

\footnotetext{
79 Bakhtin, Discourse 293 .

8 o Ibid. 342.

$81 \quad$ Ibid. 346 .

82 "Within the arena of almost every utterance an intense interaction and struggle between one's own and another's word is being waged, a process in which they oppose or dialogically interanimate each other. To ignore this basic fact about language is to transform, and literally kill, the original animated speech, turning it into something 'utterly reified, a thing." Bakhtin, Discourse 354-5.

83 Ibid. 261. It should also be noted that Bakhtin did not intend by "novel" a distinct, modern style of representation, but rather a dialogic "force" that appears with particular energy in periods of history in which opposing world views are struggling against each other. Clark and Holquist, Mikhail $276-7$.
} 
have their place alongside more sober themes. Consider, for example, the biography of one al-Ḥasan al-Numayrī al-Makīn:

Everyone used to have fun with him; they called him "kitty" (numayr), meaning the cat. Once when our companion 'Alā' al-Dīn al-Usfūnī traveled to the Hijaz, he put some flour in a sack, but the mice got to it, so he wrote to al-Makin a petition whose beginning was:

"Your servant, the flour, kisses the ground beneath your hands, O King of the Cats, the Extraordinary Pussy, the Glorious Feline, the Wise Cat! May God protect you from harm, bring you felicity!" 84

The grand style of the letter, of which I have only quoted here a portion, is an obvious parody of official petitions. The only apparent reason for writing the letter is to entertain and mock the rigid discourse of the bureaucrats. Indeed, alUdfuwi may well have included the biography of al-Makin just so that he could insert this parody of high style in his history. This would explain why he felt the need to justify his inclusion of al-Makīn in the book: "I saw him in a dream, and I had not written about him in this history. He said, 'Why don't you write about me?' So, I wrote about him." ${ }^{85}$ But this reveals more than just al-Udfuwi's sense that he might need a justification for including a biography dedicated to pure joy in his compilation of "scholars." The biography, as a genre, would seem to be a form given to completeness; most biographies have a clear beginning and a distinct end in death, sometimes articulated in details down to the very time of the day. Yet al-Udfuwi entirely undermines this assumption: His subject appears to him in a dream, after his death, and scolds al-Udfuwī for excluding him. Al-Udfuwī complies with the specter's demand, but does so by turning his life into an occasion for laughter.

Several elements in this correspond with a fundamental element of Bakhtin's conception of heteroglossia: carnival. More than just a joyous occasion of decrowning and turning the world upside down, carnival is a state of being and an attitude toward the world with a philosophical critique. As a mode of being in which the world and its ability to surprise is joyously embraced, carnival can be thought of as "a kind of existential heteroglossia." ${ }^{86}$ Carnival's literary expression is characterized by "grotesque realism," which celebrates the body's ambiguous nature through representations of the world's physical

$84 \quad$ Al-Udfuwi, Țali' 191.

85 Ibid. 192.

86 Clark and Holquist, Mikhail 301. 
nature as both the source of all life and as something fundamentally flawed. ${ }^{87}$ Laughter and parody are essential to carnival, which seeks to overturn all claims to univocal, unchanging truth by appealing to the physical ambivalence in everyone's nature. In carnival, the body is celebrated as an unending, impervious force which, even in death, produces new life, as in animal sacrifices. Laughter is, in this sense, an unveiling of apparent truths, revealing the familiar and grotesque materiality residing in all existence. ${ }^{88}$ By dialogizing everything, carnival can also thereby rejuvenate what it comes into contact with. ${ }^{89}$ The need to laugh and experience a renewal of the soul through merriment requires justification, especially if it were to occur near sacred precincts, a tendency directly parallel to al-Udfuwi's sense that he needs to justify including parody. ${ }^{90}$ It is, to some extent, expected that al-Udfuwī, the revivor of dead memories, would embrace this carnivalesque attitude toward life.

Bakhtin developed his idea of carnival on the basis of real medieval European decrowning festivities, which overturned the physical order. The Nūrūz festival, celebrated in Egypt at the time al-Udfuwi was writing, has been compared to Bakhtin's idea of "carnival." ${ }^{\text {"1 }}$ During this festival, people were known to drench each other with water, choose a poor fellow to be king, and make mischief and disorder in the streets. In al-Udfuwī's telling, Nūrūz was not condemned by the 'ulam $\vec{a}$ ' in Upper Egypt. Rather, al-Udfuwī relates in his biography of Majd al-Dīn al-Qushayrī b. Daqīq al-Īd a single, positive reference that portrays the day of carnival as part of the culture of madrasa:

Despite his scrupulousness and austerity, he was given to elation (basța). Our colleague, the qā $\bar{l} \bar{\imath}$ and erudite faqīh Nāsir al-Dīn 'Abd al-Qādir b. Abi l-Qāsim al-Asnāī said: Our shaykh Bahā’ al-Dīn al-Qifṭī said, "I found a matter of legal disagreement in a notebook, so I locked my door and began studying it. It was the day of Nūrūz and the students were playing and soaking each other with water. They demanded that I go out to them and join them. I refused and focused on the legal matter, so they started to throw the water at my house to the point that I feared that the water would get to me. Then I wrote on a piece of paper to the Shaykh, and I handed it to my slave. She entered and then returned to me; the Shaykh

\footnotetext{
$87 \quad$ Ibid. 299 .

88 Bakhtin, Rabelais 118-20.

89 Ibid. 123.

$90 \quad$ Ibid. 77.

91 Shoshan, Popular $48-9$.
} 
had written: "This is the recompense $(j a z \bar{a})$ of he who would hold himself above his colleagues!" "92

Here we see a classic expression of carnival: the casting aside of regular order, hierarchy, and conventions. Attempts at isolation, to draw oneself apart to study the law, are physically transgressed by the fundamental life-generating, yet ambiguous (it can both cleanse and humiliate), presence of water. Majd al-Dīn al-Qushayrī, the shaykh in the above anecdote, was a towering figure of Sunni orthodoxy (he is credited with removing Shici dominance in Qūss), and alUdfuwi inserts five hadīth he heard that were transmitted on the authority of Majd al-Din in his biography. Though the latter's credentials as a bearer of the official and sacred traditions are impeachable, it is with his approval that the merrymaking continued. In his words, it is not only an optional release from work, routine, and sobriety but a just punishment ( $j a z \bar{a})$ for people who try to resist.

In other cases in the T⿱ālic, it is the human body that permits transgression of official norms and hierarchy reversal. In Majd al-Dīn's biography, al-Udfuwī describes his "generosity" with food that was entrusted to him for safekeeping. At one point, a man came to Majd al-Dīn to ask for some food on the condition that he would return it at harvest. The harvest came, but the man did not return. Then, in the next year, he came back to Majd al-Dīn asking for more food, and the shaykh obliged his request. When his son-in-law criticized this act-after all, the food was entrusted to Majd al-Dīn and not really his to give - the shaykh merely replied: "If you were the one in need, would you object?"93 An action questionable under the law is sanctioned by the body, which, in its universality, allows for empathy even with strangers like the hungry man. Majd al-Dīn, it should be noted, was no hedonist; like many religious scholars of his day, he was an ascetic. But, according to al-Udfuwī, his asceticism was not due to any hatred of the body nor was it the result of a desire to transcend the world he lived in. Rather, his asceticism was the result of his attempt during a year of famine to live in conditions equal to the people of his region. Upon learning that the people were eating grass out of desperation, Majd al-Dìn "became determined to eat only what the people eat." When the famine passed, he continued to eat this way, saying "my appetite for food has been lifted, so I no longer care about what I eat. The same goes for my desire for clothing, so I no longer care about what I wear. The same also goes for my desire for social prestige $(j \bar{a} h) .{ }^{\prime 94}$

92 Al-Udfuwi, Ṭāli 431.

93 Al-Udfuwi, Tâali 431.

94 Ibid. 43 o. 
The body is the great equalizer, and its needs, pains, desires, and undeniable demands amount to a voice that cannot be ignored, even at the risk of violating social order. In another anecdote about Bahā' al-Dīn al-Qifțī, it is the ability of legal officials to feel pain and discomfort that transcends social and legal conventions and hierarchies:

Another person demeaned him (by treating him as a social peer) at court, so he jailed him. Then he went up to the roof, and he lay down on a wooden board and leather mat. It was a hot night, and he turned from side to side. Then he stood up on the roof and yelled from the top of the roof: "Go find so-and-so for me and bring him to me!" When the person came, he said, "Release so-and-so from jail." When it was morning, they asked him about it. He replied, "I went up to the roof, and I had a leather mat under me. I started to turn from side to side from the heat, and I asked myself, 'What must it be like for that person?' "95

While the social norms of court require respect, it is the body which establishes its own exigent demands.

The above examples are limited cases of the carnivalesque insofar as the voice of the body, the people, and laughter never completely overturn the social hierarchy. Rather, al-Udfuwi seems to be more interested in representing the validity of the body and physical enjoyment on a par with the scholarly and spiritual pursuits valorized on so many pages of the book. At times, it appears that food is mentioned for its own sake, such as a story about Diyā' al-Dīn Ja'far al-Qinā'ì, a respected $q \bar{a} d \bar{\imath}$ and $m u f t \bar{\imath}$ who al-Udfuwī claims was said to be fit to be caliph. When someone went to visit him at his house, al-Qināì opened his door, "holding in one hand kinăfa with sugar and a baby dropper in the other. He said, 'I desired this, and the little one desired that." "96 Part of the reason for including an anecdote like this may well be to show that al-Udfuwī had access to the private lives - even the bodies themselves - of the scholars he wrote about, even ones he did not know well. But one can also see here a tendency to revel in food and consumption so characteristic of the carnivalesque. According to Bakhtin, "No meal can be sad. Sadness and food are incompatible."97 Al-Udfuwī would likely have agreed. Indeed, Ibn Ḥajar wrote that al-Udfuwī was, despite his (era-appropriate) asceticism, someone who enjoyed “delightful

$95 \quad$ Ibid. 696.

96 Al-Udfuwi, Țālic 184.

97 Bakhtin, Rabelais 283 . 
food." ${ }^{98}$ According to al-Ṣafadī, who knew him personally, al-Udfuwī was "jolly (dahük al-sinn) and used to spend his days off from the life at the madrasa in an orchard (bustān) of his in Udfü."99

For al-Udfuwī, a person's good-naturedness manifests itself in the ability to embrace the body and its messages, as we saw with Majd al-Dīn above. Spiritual isolation, on the other hand, was a matter of disapproval. Hence, in a rare passage where al-Udfuwì describes an internal change that a person undergoes, it is about the transition from an openness to the world to a state of seclusion. The passage appears in the biography of al-Udfuwì's friend, Sālih b. 'Abd al-Qawwī l-Asnā'ì, who had a "sonorous voice" and studied music (al-Udfuwī's passion). "He used to be merry (țarūb) and good-natured (hasan al-akhlāq),"100 but something happened to him after he moved to Qūṣ:

He was overcome by melancholy (al-sawd $\left.\bar{a}^{\prime}\right)$, and his condition changed. His mind was corrupted (hașal lahu khabāl), so that he only spoke rarely and only acknowledged you if greeted first. His joy (tarab) and amiability left him. He isolated himself in a chamber in Shaykh Bilāl's ribāt, then in another in Shaykh 'Abd al-Ghaffār's ribāt, detaching himself from people. He continued in this way until he died ... When I would go to Qūs, he would refuse to sit with me. I would seek him out and greet him, but he would only greet me back. ${ }^{101}$

Far from being a positive quality, spiritual isolation here appears to be a result of a disease of the mind, a sickness that affects both soul and body. Health, on the other hand, entails conviviality, joy, and enjoyment of physical beauty. This tarab, the joy one experiences upon listening to music, could manifest itself as a cheerful disposition to death as well as life. For example, al-Udfuwì writes admiringly about the judge and Shāfi'i faqīh 'Abd al-Qawwī b. Muhammad that he was "high-spirited (khafíf al-rüh) and good-natured (hasan al-khulq)." He was also a friend of al-Udfuwì's family who "loved sama $\bar{a}^{c}$ so much" that he requested that musical instruments play at his funeral and weeping women be banned. ${ }^{102}$

Al-Udfuwī, both a faqīh and a lover of music and joy, moved in multiple worlds: the religo-legal and the aesthetic and corporeal. Living in both worlds

\footnotetext{
98 Ibn Hajar, Durar i, 536 .

99 Al-Ṣafadī, Wāfı xi, 78; see also Ibn Hajar, Durar i, 535 .

100 Al-Udfuwi, Țālic 270.

101 Al-Udfuwi, Țālic 270.

102 Ibid. 333 .
} 
implied for him no contradiction. In this, we learn from his history, he was not alone. Consider, for example, his biography of another of his friends, the notary and poet 'Alä' al-Dīn 'Alī al-Usfūnī, who was the author of the letter to the king of the mice mentioned above:

I associated with him for quite some time and saw of him extraordinary noble-mindedness and virtuous action. He was so pleasant he seemed to have been created from a gentle breeze. He was in love with beauty itself, so any comely face would capture every crevice of his heart. When seen, he was always in a state of tranquility. Like a moist twig on which the wind alights, he would quiver and rock with joy (taraban). He was a knight in the hippodrome of adāb and Hasān's brother in odes. He stayed for many years with us in Udfü when his father was the notary (shähid) of the dīwān, and being in his company abolished sorrows and ushered in joys.

Like many of al-Udfuwi's associates, he received training in figh and used this to get a job in the administration as a notary. This did not prevent him from also loving physical beauty and allowing himself to be enraptured by it. Far from sullying his reputation, this was, for al-Udfuwì a sign of his good-naturedness. This good-natured openness to life could lead to carnivalesque behavior, such as in the following story al-Udfuwī relates about al-Usfūnī:

His father once bought him a garment to clothe himself in. A person later asked him for it, and he gave it to him. So, his father bought him another garment, and he took it. Then his father said to him, "Tell me, what would you have done if the woman you love came to you?" He replied, "I'd cover up with her in her robe ( $\left.r i d \bar{a}^{\prime}\right)$ !" His father asked, "But what if she didn't have a robe $\left(r i d \bar{a}^{\prime}\right)$ ?" He replied, "Then I'd say to her, 'Go away til the summer!"

His altruistic act of disrobing himself for the sake of another was ridiculed by his own father, who reminded him of his social responsibility, but this was just another opportunity for al-Usfūnī to show his good humor, turning it into a joke with clear sexual undertones (sharing a robe). Simultaneously, he reversed gender roles: He would seek shelter from a woman. When pressed by his father for a serious answer, he showed his disdain even for sexual desire if it meant keeping a garment all to himself; his love could come back when the seasons shift and the warm summer air obviates any need for heavy garments. Here we see a classic expression of the attitude of carnival: a disrobing (a loss of status) leads to a reversal of roles. 
This knight of $a d a b$ was trained (ta'addab 'alā) by a local poet and litterateur, Sharaf al-Dīn b. al-Ghaḍanfar, famous for his mujūn (profligate behavior). According to al-Udfuwī, who included an entry on Ibn al-Ghadanfar in his history:

Sharaf al-Dīn would often act shamelessly and with profligacy (kathìr almujūn wa-l-khalä́a). Many famous stories are told about him. Our colleague 'Alā' al-Dīn b. al-Shihāb told me, in his words, "Once, Sharaf al-Dīn b. al-Ghadanfar was sitting by the door of the mosque in Usfūn. The call for the afternoon prayer had finished, and a person from among the locals in Usfūn had done his ablutions and arrived to enter the mosque. He saw Sharaf al-Dīn and said, 'The afternoon call to prayer has finished while you were sitting here. Why don't you get up and do your ablutions?' So Sharaf al-Dīn replied, 'My sitting here is better than your prayer without an ablution.' The person, who had done his ablutions, shook his beardit was wet with water-to show him that he had done his ablutions. Then Sharaf al-Dīn replied, 'You've polluted me (najjastanī).'” His tales are many.

Ibn al-Ghadanfar is able to mock even the most solemn aspects of official religion: ritual prayer. Many of these stories about mujūn are related by alUsfūnī. ${ }^{103}$ This brings our attention to two points. First, the shape of al-Udfuwī's book, and the heteroglossia therein, are highly dependent on his sources, a point I will return to shortly. Second, mujūn literature, a classic genre by alUdfuwi's age, was not only appreciated by the notaries, jurists, and poets who populated his history and composed his target audience but was, in fact, seen as a legitimate mode of expression distinct from the high religious register that, as we saw, introduced and justified al-Udfuwī's history.

This takes us to the second major cause of heteroglossia in al-Udfuwi's history: the recognition of different, even contradictory, modes of speaking. This is something that al-Udfuwī notes explicitly in his book and makes an effort to distinguish as distinct voices with distinct world views. For example, in an entry on the poet and polymath al-Sadīd Muhammad Ibn Kātib al-Marj, whom al-Udfuwi describes in highly poeticized, almost fawning saj', he claims that alSadid followed the "madhhab of the ahl al-adab in which they extol the beauty of the youth, compose verses on wine and describe their lovers." ${ }^{104}$ Like the

103 The acts of two other mujūn poets in al-Ṭälic are also related by 'Alā al-Dīn al-Usfūnī. AlUdfuwī, Țālic $226-9$.

104 Al-Udfuwī, Țālic 6o3. 
modes of thought characteristic of law, religion, and philosophy, the ahlal-adab also receive their due, without criticism but rather with prose dripping with admiration and praise. One finds a nearly identical expression of this duality in another biography, this time of a poet, preacher (khațīb), and Shāfici faqīh who studied with al-Nawawī (d. 676/1277), 'Abd al-Rahịm al-Samhūdī. In al-Udfuwī's words, "He was gentle, pleasant and high-spirited, following the madhhab of the ahl al-adab in his love of drink, young men, and rapture (tarab)." ${ }^{105}$ Following the path of $a d a b$ is no cause for censure; we find none of the condemnations of these practices that we see in some of the biographies of Shicis or popular beliefs. Indeed, for al-Udfuwī, the physical land's abundance in itself is a cause of ambiguity and dualism. This is expressed in a poem about Aswan he includes in his preface:

Aswan is a half-circle in which good and evil have united

It is a suitable residence for the pious worshiper and the wanton sinner alike.

One acquires yearning for its women, tall and slender like the Moringa tree,

And the other, divine reward for his prayer. ${ }^{106}$

The third major source of heteroglossia emerges from al-Udfuwi's attempt to represent his shuyükh as founts of orthodoxy and correct practice. In order to do this, the variant, heterodox practices also emerge in the biographies. As a result, we see the ironic preservation of those voices whose authority he attempts to undermine. This is true of heterodox beliefs about Sufi miracles, or karāmat. Al-Udfuwi takes the liberty in two biographies of describing what kinds of reports regarding Sufi miracles can be accepted as possibly true. The first occurs in the biography of al-Mulaththam (d. 671/1273), of whom al-Udfuwi has little to say beyond including reports about his longevity (some said he was a close relative of Yūnus or that he had prayed with al-Shāfiī) or his ability to be in two places at once. Al-Udfuwi quotes these fantastic stories only to switch to a discourse on heretical opinions spread by some Sufis, relating an opinion attributed to Ibn al-Salāh (d. 643/1245) and Ibn 'Abd al-Salām that people who claim to have seen God on Earth should be punished. ${ }^{107}$ The second place where al-Udfuwī writes about the acceptability of reports about karāmat is in the biography of the majdhūb and popular ascetic Mufarrij b. Muwaffaq

105 Ibid. 313.

106 Ibid. 33 .

107 Al-Udfuwī, Ṭălic 131-5. 
al-Damāmīnī (d. 648/1250). Al-Udfuwī includes several minor miracles, including one that would require al-Damāmīnī to be in two places at once. Al-Udfuwī then includes a long discussion on the impermissibility of accepting reports about karāmat contrary to experience. ${ }^{108}$ Clearly, part of al-Udfuwīs purpose here is to reinforce Sunni figh and ușül al-dìn as the arbiter of correct belief and confirm the dominance of the scholarly, textual traditions over the embodied, popular religious traditions of the region. A similar motive seems to undergird his description, and condemnation, of the carnivalesque atmosphere of the annual remembrance of the day Abū l-Ḥajjāj al-Uqșurī (d. 642/1244) supposedly rose to heaven and met God. ${ }^{109}$ Yet, in doing so, he also preserves for us a taste of the beliefs and practices of the region.

The final, and most important reason, for heteroglossia in al-Țălic, is alUdfuwī's eclectic interests and sources. According to his biographers, al-Udfuwī was known as someone who read widely and profusely. He was also someone known for his understanding of music and poetry, in addition to his training as a faqih and muhaddith and his love of history. As noted above, specializing in music was something of a family tradition, and al-Udfuwī was the author of a respected essay on the legality of $s a m \bar{a}^{c}$ and music. In the Țălic, his interest in music is reflected in the several anecdotes describing individuals either approving or turning a blind eye to enjoying music. ${ }^{110}$

His range of interests is reflected in the number of sources he cites in alTálic. I counted 70 distinct written texts, although this is only an estimate, for he often refers to the khatt of people he knew, and it is not always clear what kind of text he is referring to. His sources included popular siras, rijäl-style histories, and anthologies of poetry spanning several centuries. In addition, he refers to the tabaquat al-sama $\bar{a}^{c}$ that he found in the colleges and libraries he had access to. We know he went searching through books at the madrasa alNajībiyya in Qūṣ for information, and sometimes these audition notices are the only information he provides about people. ${ }^{111}$ We also know from al-Ṣafadī, his contemporary and acquaintance, that he used to sit in the booksellers' market in Cairo, so we can assume he had access to a wide selection of sources. He also cites tombstones he found in the Șaīid, several official documents, records

\footnotetext{
108 Ibid. 649-55.

109 Al-Udfuwī, Tālic 724.

110 In addition to the references above, see ibid. 161-2, 190, 251, 537, 584.

111 The tabaqat al-sama $\bar{a}^{c}$ to which he refers to the most, by far, and is the only source for several biographies, is a record of a hadīth reading conducted by Ibn Daqīq al-Ī̃d in Qūṣ in the year 659/126o-1. Ibid. 62, 73, 185, 215, 232, 252, 276, 363, 420, 552, 6o2, 637, 639, 664, 665, 740 .
} 
of individuals' 'adāla or testifying their orthodoxy, and appointment letters arriving from Cairo. These span a range of almost 200 years. ${ }^{12}$ All of this is in addition to the orally transmitted anecdotes and poetry, which compose the majority of his material.

The result is a mesmerizing cacophony of voices that seem to mimic the polyphony of reality itself. His ability to pull from a wide array of sources helped him produce a representation of his region that appeared, despite his subtle omissions and editorializations, to be a faithful resurrection of the past. In many ways, al-Udfuwi's stated goal must be seen as a success. His biographers are unanimous in their approval of his historical work, without a peep about his family's sectarian heritage. For example, al-Maqrīzī, in his own biographical dictionary, was forthright about his admiration of al-Udfuwi's work: "I copied a lot from it in this book. It is a precious book containing stories and biographies not found in any other." He had, al-Maqrīzī added, "thorough knowledge of history (ma'́rifa tāmma bi-l-tārīkh)." ${ }^{\prime 13}$ What may have pleased al-Udfuwī the most, however, is the success of his biography of Ibn Daqī al-'̄̄d, a towering figure whom al-Udfuwi never had the chance to see, something which, he writes, caused him pain, although he assures his readers that he benefited in both youth and old age from reading his books. ${ }^{114} \mathrm{By}$ far the longest entry in the Taalic, Ibn Daqī al-'̄̃d's biography is the centerpiece of the book. Al-Udfuwī, relying on oral reports, hints that Ibn Daqī al-Īd may have been a mujtahid and that his best work never saw the day of light. ${ }^{115}$ Ibn Daqiq al-'̄d was in many ways exemplary of the ambiguous nature of al-Udfuwi's entries: The premier shaykh whose accolades are universally recognized, his biography is also filled with satiric verses written by others about him, much of which he seems to have approved. ${ }^{116}$ He was not, moreover, above composing his own raunchy jokes in verse. ${ }^{117}$ His deep knowledge of Ibn Daqīq al- $\bar{I} d$ and his familiarity with many of his students seem to have led later scholars to believe that al-Udfuwì was actually the former's student. Hence, Ibn Hajar writes that he "studied closely with Ibn Daqīq al-Īd." 118 Attributing such an honor to al-Udfuwi may be the best testimony to his ability to represent his subjects with intimacy and to portray himself as the inheritor of their knowledge.

\footnotetext{
112 For appointment letters: Al-Udfuwī, Țālic $381-2,477,515,530,556$; ijāza: 357, 363, 393, 433, 443, 556-7, 719; testimonies of character: 102, 253, 295, 308, 352, 535; tombstones: 474 .

113 Al-Maqrīzī, Muqaffā iii, 23. See the similar remark in al-Ṣafadī, Wāfì xi, 78.

114 Al-Udfuwī, Tālic 599 .

115 Ibid. 569, 576 .

116 Ibid. $585^{-7}$.

117 Ibid. 583 .

118 Ibn Ḥajar, Durar i, 535 .
} 
In his tamhīd, al-Udfuwī establishes a correspondence between God's resurrection and the act of writing history, thereby lending his biographies a veneer of verisimilitude. They appear to be objective representations of the people of his region. By extending the metaphoric imitation of God to the act of historiography, al-Udfuwī justifies inscribing moral, immoral, and ambiguous actions and actors in historical memory. One of the purposes of the craft ( fann) of history $(t \bar{a} r \bar{k} k h)$, al-Udfuwī tells his reader in his introduction, is to be able to discern the virtuous from the degenerate. It is likely that al-Udfuwi was aware that the metaphor of resurrection and judgment could extend to the reader, who, presented with the resurrected lives in his history, was encouraged to form judgments about their moral character.

It is, moreover, due to his interest in a local region, and not just a particular group of individuals or professional class, that his biographies extend to a multitude of different individuals, modes of speaking, and ideas. The representation of the different voices, like the madhhab of the lovers, the heterodox tendencies of his family, the messages conveyed by the body, and the Sufis, heighten the reader's sense of the author's objectivity through a studied use of subjectivity; we seem to see some of the individuals just as al-Udfuwi (or his informants) did-eating, sleeping, teaching, joking, etc. Yet the careful exclusion of the region's political upheavals and the delicate evaluation of his family pedigree give one the sense that al-Udfuwi is trying to show his readers something about Upper Egypt: It is a region chock-full of a host of poets and scholars with whom al-Udfuwī is closely associated. There is no reason to think, however, that this intention overly obscures the value of the book as a historical source. At the least, al-Udfuwis's "jolly" nature and his partiality to comedy and carnival would appear to have inspired him to include some entries just for the sake of recording an entertaining anecdote. Certainly, this seems to be true for the entry on the "King of the cats."

Although the literary aspects of al-Udfuwi's history are undeniable, one still wonders if this is due to its biographical genre. After all, Arabic biographical works, long before al-Udfuwi's time, were replete with literary elements; one can point, for example, to the common inclusion of poetry. But it should also be remembered that al-Udfuwi tells us that he wrote a history (tärïkh). Indeed, al-Udfuwi downplays the difference between chronicles and biography. As he notes in regard to history (tärīkh): "The virtuous masters and knowledgeable leaders have written books as numerous as the stars on it (i.e., history). There are those who have organized (it) according to years, and there are those who have organized (it) according to names, in order for its isnād (chain of trans- 
mission) to be more reliable. There are those who have constricted it to a particular country, and there are those who have encompassed every corner of the world."119 For al-Udfuwi, the organization of the text according to name or its restriction to a particular region, as in the case of the Taalic, does not make it a less historical text than a chronicle. History, like the resurrection, has a moral purpose, yet this does not exclude the possibility of entertainment. Biographies for him, then, are not more literary in nature than chronicles (even if this may be true of most biographies). Certainly, they are not more fictitious. If anything, the organization of history according to biographies promises the kind of clarity and perspicacity only possible through the resurrection of people.

\section{Bibliography}

\section{Primary Sources}

al-Askarī, A., Kitāb al-șinā'atayn, ed. A. al-Bajāwī and M. Ibrāhīm, Cairo 1952. al-Gharnāțī, M., al-Baḥr al-muhịṭ, ed. A.A. 'Abd al-Mawjūd et al., 8 vols., Beirut 1993. al-Ghazālī, A., al-Maqșad al-asnā fì sharh ma'āni asmā̄’ Allāh al-ḥusnā, ed. F. Shehadi, Beirut 1971.

al-Hillī, 'A., Sharh al-kāfiya al-badīìyya fì úūm al-balāgha wa-mahāsin al-badī', ed. N. Nashāwī, Beirut 1992.

Ibn 'Abd al-Salām, 'A., Shajarat al-ma'ārif wa-l-aḥāl wa-șālih al-aqwāl wa-l-a'māl, ed.

I. Khalid, Damascus 1998.

Ibn al-Athīr, D., al-Mathal al-sā̄ir fì adab al-kātib wa-l-shāìir, ed. A. al-Hūfī and B. Ṭabāna, 4 vols., Cairo 1959-65.

Ibn Hajar, A., al-Durar al-kāmina fi àyān al-ma’a al-thāmina, 4 vols., Hyderabad 192932.

Ibn al-Imād, A., Shadharāt al-dhahab fí akhbār man dhahab, ed. M. al-Arnā'ūț, 10 vols., Beirut 1986.

Ibn al-Mu'tazz, A., Kitāa al-badī', ed. 'A. Mutrajī, Beirut 2012.

Ibn Qādī Shuhba, A., Țabaqāt al-Shāficiyya, ed. A. Khān, 5 vols., Hyderabad 1978.

Ibn Taymiyya, A., al-Radd 'alā al-Shādhilīfí hizbayh wa-mā șannafah fi adāb al-țarīq, ed.

A. al-Imran, Mecca 2008.

Ibn Taymiyya, Kitāb al-Șafadiyya, ed. M. al-Aḥmadī, Beirut 2007.

al-Isnawī, 'A., Ṭabaqāt al-Shāfíiyya, ed. K. al-Ḥ̄t, 2 vols., Beirut 1987.

119 Al-Udfuwī, Tālic', 3. 
al-Maqrīzī, A., al-Sulūk li-márifat duwal al-mulūk, ed. M.'A 'Ațā, 8 vols., Beirut 1997.

al-Maqrīzī, A., al-Mawāi iz wa-l-i'tibārfì dhikr al-khițațwa-l-athār, ed. A.F. Sayyid, 4 vols., London 2003.

al-Maqrīzī, A., al-muqaffā al-kabìr, ed. M. Yalaoui, 8 vols., Beirut 2006.

al-Qalqashandī, A., Subḥ al-a'shā, Cairo 1922.

al-Qurțubī, A., al-Asnā fì sharh asmā̄ Allāh al-ḥusnā wa-șifātuh, ed. 'I. Ḥassūna, Beirut 2005 .

al-Qurțubī, A., al-Jāmi li-aḥkām al-Qur'ān al-mubayyin li-mā tadammanah min alsunna wa-āy al-Qurān, ed. A. al-Turkī, 24 vols., Beirut 2006.

al-Qushayrī, A., Sharh asmā̄ Allāh al-ḥusnā, Beirut 1986.

al-Qushayrī, A., al-Risāla al-qushayriyya, ed. A. Maḥmūd and M.b. al-Sharīf, Cairo 1989.

al-Ṣafadī, K., Kitāb al-wāfi bi-l-wafayāt, ed. A. al-Arnāūụt and T. Mușțafā, 20 vols., Beirut 2000.

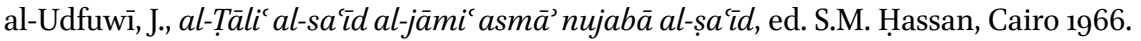

\section{Secondary Sources}

Auerbach, E., Mimesis: The representation of reality in western literature, trans. W. Trask, Princeton 2003.

Bakhtin, M., Discourse in the novel, in M. Holquist (ed.), C. Emerson and M. Holquist (trans.), The dialogic imagination, Austin 1981, 259-422.

Bakhtin, M., Rabelais and his world, trans. H. Iswolsky, Bloomington 1984.

Chittick, W., The Sufi path of knowledge: Ibn al-Arabi's metaphysics of imagination, Albany 1989.

Clark, K., and M. Holquist, Mikhail Bakhtin, Cambridge 1984.

Cooperson, M., Classical Arabic biography: The heirs of the prophets in the age of alMa'mūn, Cambridge 2000.

Daftary, F., The Ismāìlīs their history and doctrines, Cambridge 1990, ${ }^{2} 2007$.

Fahndrich, H., The wafayāt al-a'yān of Ibn Khallikān: A new approach, in JAOs 93/4 (1973), 432-45.

Fahndrich, H., Compromising the caliph: Analysis of several versions of an anecdote about Abū Dulāma and al-Manșūr, in JAL 8 (1977), 36-47.

Freimark, P., Das Vorwort als literarische Form in der arabischen Literatur, PhD diss., Universität Münster 1967 .

Garcin, J., Un Centre musulman de la Haute-Égypte Médiévale: Qūṣ, Cairo 1976.

Gharaibeh, M., Narrative strategies in biographical dictionaries: The ad-Durar alKāmina of Ibn Hağar al-'Asqalān̄-A case study, in S. Conermann (ed.) Mamluk historiography revisited -Narratological perspectives, Bonn 2018, 51-76.

Goitein, S., Studies in Islamic history and institutions, Leiden 2010.

Gril, D.,'Abd al-Rahīm al-Qinā'̄̄, $E I^{3}$. 
Gril, D., Abū l-Ḥajjāj Yūsuf al-Uqșurī, $E I^{3}$.

Groff, P., Al-Kindī and Nietzsche on the stoic art of banishing sorrow, in Journal of Nietzsche studies, 28 (2004), 139-73.

Haarmann, U., Auflösung und Bewahrung der klassischen Formen arabischer Geschichtsschreibung in der Zeit der Mamluken, in ZDMG 121/1 (1971), 46-6o.

Hofer, N., The popularisation of Sufism in Ayyubid and Mamluk Egypt, 1173-1325, Edinburgh 2015.

el-Leithy, T., Sufis, Copts and the politics of piety: Moral regulation in fourteenthcentury Upper Egypt, in R. McGregor and A. Sabra (eds.), Le développement du soufisme en Égypte à l'époque mamelouke. The development of Sufism in Mamluk Egypt, Cairo 2006.

Holt, P., Kanz, Banu 'l, $E I^{2}$.

Makdisi, G., Ash'arī and the Ash'arites, in Islamic religious history I, in $S I$ 17 (1962) 378o.

Makdisi, G., "Tabaqāt" - Biography: Law and orthodoxy in classical Islam, in Islamic studies 32/4 (1993), 371-96.

Malti-Douglas, F., Controversy and its effects in the biographical tradition of al-Khațîb al-Baghdādī, in SI 46 (1977), 115-31.

Malti-Douglas, F., Dreams, the blind, and the semiotics of the biographical notice, in $S I$ $51(1980), 137-62$.

Orfali, B., The art of the Muqaddima in the works of Abū Manșūr al-Tha'ālib, in L. Behzadi and V. Behmardi (eds.), The weaving of words: Approaches to classical Arabic prose (Beiruter Texte und Studien 112) Würzburg 2009, 181-202.

Orfali, B., and P. Maurice, "I see a distant fire": Tha'ālbī's (D. 429/103o) Kitāb al-iqtibās min al-Qurān al-karīm, in N. Alshaar (ed.), The Qur'an and adab: The shaping of literary traditions in classical Islam, Oxford 2017, 191-215.

Qutbuddin, T., Khuțba: The evolution of early Arabic oration, in B. Bruendler (ed.) Classical Arabic humanities in their own terms, Leiden 2008.

Qutbuddin, A., Tahmid: "A literary genre? A study of the Arabic laudatory preamble with a focus on the Fatimid-Tayyibi tradition," PhD diss., School of Oriental and African Studies 2009.

Rapoport, Y., Invisible peasants, marauding nomads: Taxation, tribalism and rebellion in Mamluk Egypt, in MSR 8/2 (2004), 1-22.

Riexinger, M., Rendering Muḥammad human again: The prophetology of Muhammad b. 'Abd al-Wahhāb (1703-1792), Numen 6o (2013), 103-18.

Robinson, C., Islamic historiography, Cambridge 2003.

Rosenthal, F., A history of Muslim historiography, Leiden 1952, ${ }^{2} 1968$.

Saleh, W., Ibn Taymiyya and the rise of radical hermeneutics: An analysis of an introduction to the foundations of Qur'ānic exegesis, in Y. Rapoport and S. Ahmed (eds.) Ibn Taymiyya and his times, Karachi 2010, 123-62. 
Shahzad, Q., Ibn 'Arabī's contribution to the ethics of divine names, in Islamic Studies 43/1 (2004) 5-38.

Shoshan, B., Popular culture in medieval Cairo, Cambridge 1993.

Stern, S.M., The succession to the Fatimid Imam al-Āmir, the claims of the later Fatimids to the imamate, and the rise of Tayyibì Ismailism, in Oriens 4 (1951) 193-255.

Wansleben, J.M., The present state of Egypt: Or, a new relation of a late voyage into that kingdom performed in the years 1672 and 1673 , London 1678 . 